\title{
Integrated spatial assessment of wind erosion risk in Hungary
}

\author{
László Pásztor ${ }^{1}$, Gábor Négyesi ${ }^{2}$, Annamária Laborczi $^{1}$, Tamás Kovács $^{3}$, Elemér László ${ }^{2}$, and Zita Bihari ${ }^{3}$ \\ ${ }^{1}$ Institute for Soil Sciences and Agricultural Chemistry, Centre for Agricultural Research, Hungarian Academy of Sciences \\ (MTA ATK TAKI), Herman O. u. 15, 1022 Budapest, Hungary \\ ${ }^{2}$ University of Debrecen, Faculty of Sciences, Department of Physical Geography and Geoinformatics, 4010 Debrecen, \\ Egyetem tér1, Hungary \\ ${ }^{3}$ Hungarian Meteorological Service, Department of Climate and Ambient Air, Unit of Climatology, \\ 1024 Kitaibel Pál u. 1, Hungary
}

Correspondence to: Gábor Négyesi (negyesi.gabor@science.unideb.hu)

Received: 11 May 2016 - Published in Nat. Hazards Earth Syst. Sci. Discuss.: 13 June 2016

Revised: 21 October 2016 - Accepted: 24 October 2016 - Published: 24 November 2016

\begin{abstract}
Wind erosion susceptibility of Hungarian soils was mapped on the national level integrating three factors of the complex phenomenon of deflation (physical soil features, wind characteristics, and land use and land cover). Results of wind tunnel experiments on erodibility of representative soil samples were used for the parametrization of a countrywide map of soil texture compiled for the upper $5 \mathrm{~cm}$ layer of soil, which resulted in a map representing threshold wind velocity exceedance. Average wind velocity was spatially estimated with $0.5^{\prime}$ resolution using the Meteorological Interpolation based on Surface Homogenised Data Basis (MISH) method elaborated for the spatial interpolation of surface meteorological elements. The probability of threshold wind velocity exceedance was determined based on values predicted by the soil texture map at the grid locations. Ratio values were further interpolated to a finer 1 ha resolution using sand and silt content of the uppermost $(0-5 \mathrm{~cm})$ layer of soil as spatial covariables. Land cover was also taken into account, excluding areas that are not relevant to wind erosion (forests, water bodies, settlements, etc.), to spatially assess the risk of wind erosion. According to the resulting map of wind erosion susceptibility, about $10 \%$ of the total area of Hungary can be identified as susceptible to wind erosion. The map gives more detailed insight into the spatial distribution of wind-affected areas in Hungary compared to previous studies.
\end{abstract}

\section{Introduction}

Wind erosion represents a serious problem worldwide. According to a report by the United Nations Environment Programme in 1991, the phenomenon of wind erosion is responsible for more than $46 \%$ of the total degradation of arid areas (Zheng, 2009). According to Lal (1994), the total agricultural area affected by wind erosion adds up to about 550 million ha worldwide. Oldeman et al. (1991) estimated the total European agricultural area eroded by wind to be 42 million ha. In Europe, wind erosion affects mainly the semiarid areas (Gomes et al., 2003). López et al. (1998) provide quantification of wind erosion in agricultural soils of central Aragon in Spain. Martinez-Grana et al. (2015) pointed out that hazards of wind erosion in the natural parks of Spain are acceptable, but there are regions where the risk reaches a high level. Research carried out in the 1990s in Europe (Welsons: Gomes et al., 2003; Wheels: Böhner et al., 2003) revealed that wind erosion causes more serious problems than previously thought because large areas in the temperate climate in East Anglia (England), Lower Saxony (Germany) and southern Sweden are temporarily affected by significant wind erosion events (Eppink and Spaan, 1989; Goossens, 2001; Bärring et al., 2003; Warren, 2003). Very recently Borrelli et al. (2014a, b, 2015) provided spatial assessment of land and soil susceptibility for wind erosion on a European scale.

Wind erodibility is determined by several static and dynamic factors, such as surface roughness, topographical features of surface and vegetation cover, and several pedological features, such as particle size, soil structure, aggregate 
stability, ground moisture, lime and organic matter contents, etc. (Shao, 2008).

Degradation of land caused by wind erosion strongly depends on the texture of topsoil; therefore, mapping of deflation requires knowledge of the soil texture of the uppermost soil layer in proper spatial detail (Borrelli et al., 2014a; Mezősi et al., 2015). Soil texture can be assigned the most accurately by determining particle size distribution (PSD). According to their size, different particles can be categorised as clay, silt or sand. The size intervals are defined by national or international textural classification systems. Soil textural classes are defined by the numerical proportion (weight percentage) of the sand, silt and clay separates in the fine-earth fraction $(\leq 2 \mathrm{~mm})$. The division is usually depicted in a triangle diagram, the so-called "texture triangle". If the percentages for any two of the soil separates are known, the correct textural class is determined; simultaneously, the sum of the three percentages must total $100 \%$. The most commonly used texture triangle (also in wind erosion models) among the different classification systems is defined by the United States Department of Agriculture (USDA).

The framework of digital soil mapping (DSM; McBratney et al., 2003) involves spatial inference of soil information collected at sampled points based on ancillary environmental variables related to soil forming processes. There are various methods that can be used for establishing quantitative relationships between soil properties and the environment. The recent developments of DSM have significantly extended the potential for more accurately predicting the spatial distribution of soil properties and related environmental elements (Lagacherie et al., 2007; Hartemink et al., 2008). The set of the applied DSM techniques has been gradually broadened, incorporating and eventually integrating geostatistical, data mining and geographic information system (GIS) tools (Minasny et al., 2012). Furthermore, the available auxiliary environmental information has been persistently widened. Specific novel digital soil (related) map products can be compiled that were never mapped before, even nationally with relatively high spatial resolution. The maps are created with strong emphasis on their accuracy and reliability (Pásztor et al., 2015).

Wind erosion is usually a natural, geological process that forms many aeolian landforms (Lancaster, 1995), but today it is accelerated by anthropogenic effects (overgrazing, mismanagement of agricultural lands, intensive crop cultivation etc.) In agricultural lands, wind erosion causes removal and transportation of the finest and most biologically active part of the soil, which is richest in organic matter and nutrients (Funk and Reuter, 2006). A substantial consequence is the decline in the productivity of endangered areas. Furthermore, the transport of nutrients and pre-sowing herbicides by wind erosion can also be considered as a serious environmental problem (Funk et al., 2004).

Vegetation cover plays an important role in preventing wind erosion (Armbrust and Bilbro, 1997). The presence of vegetation on the surface increases the turbulence close to the ground and therefore decreases wind velocity (Shao, 2008). If non-erodible plants cover the soil surface, soil erosion is reduced by $98 \%$ (Fryrear et al., 2000). The vegetation can also increase the soil moisture content through shading effect. Bare soil and arable lands are most seriously affected by wind erosion. Because vegetation cover alters in space and time, it is more straightforward to characterise an area only with the potential exposure, which can be characterised by susceptibility to wind erosion.

In Hungary wind erosion causes serious problems in agricultural production as well as in soil and environmental quality. According to the "Map of potential wind erosion of Hungary" by Lóki (2012), 26.5 \% of Hungary is strongly or moderately affected by wind erosion, where the critical threshold velocity of erosive winds is lower than $8.5 \mathrm{~m} \mathrm{~s}^{-1}$. However, this map is based only on a simplified soil texture classification and critical threshold velocity, whereas other factors (wind velocity, land use) were not taken into account. Thus, this map does not provide a full picture of the hazard as it was pointed out by Mezősi et al. (2015). Mezósi et al. (2015) integrated climate, vegetation and soil erodibility factors with fuzzy logic to create a wind erosion map of Hungary based on soil texture, climatological and land use data, and they verified their results by field investigation. The spatial resolution of the databases they used for representing wind erosion factors was significantly lower than the inputs of the present approach. Their verification included three test sites and did not contain comprehensive wind erodibility measurements. They took into consideration wind velocity above $9 \mathrm{~m} \mathrm{~s}^{-1}$ to represent erosive wind; however, this value differs in the case of different soils.

Our aim was to provide a nationwide spatially detailed assessment of the susceptibility of the land in Hungary to wind erosion by integrating actual and representative wind tunnel measurements, which are the latest products provided by both digital soil mapping and digital climate characteristic mapping. The most recent land cover map is provided by remote sensing (Fig. 1).

\section{Material and methods}

\subsection{Study site}

In Hungary (Fig. 2) large areas are covered by sandy and silty soils, which are mainly affected by wind erosion. More than $60 \%$ of the relatively flat area is under agriculture cultivation, which enlarges the exposure to wind erosion, causing serious soil degradation. The mean annual precipitation varies between 500 and $700 \mathrm{~mm}$; the average temperature is $10-11^{\circ} \mathrm{C}(1961-1990)$ (Péczely, 1998). The countrywide yearly average wind speed is $2-4 \mathrm{~m} \mathrm{~s}^{-1}$. The monthly average wind velocity increases continuously in the first months of the year, and the highest monthly average wind velocity 


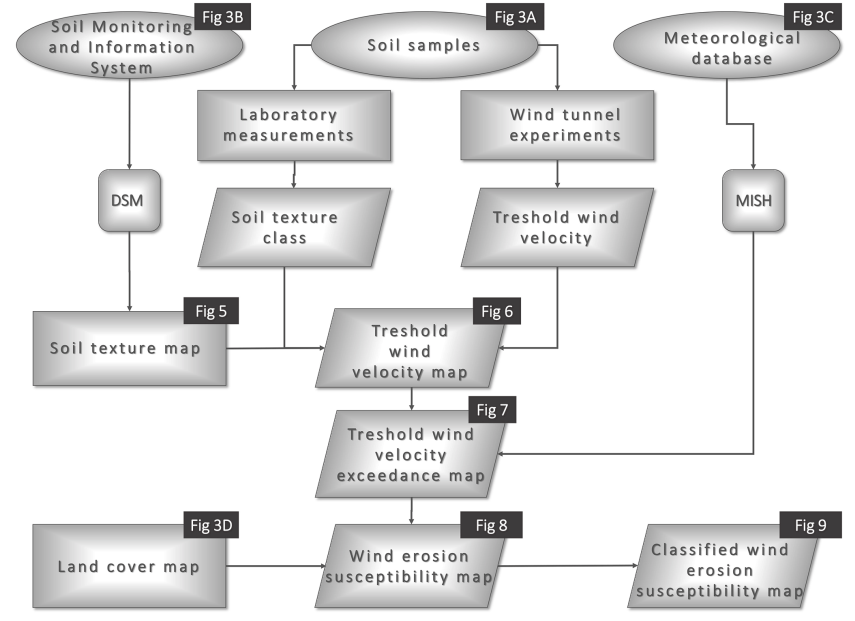

Figure 1. Scheme of the model structure with input layers and the outputs.

can be experienced in March and April (when the agricultural fields are bare). The average wind velocity reaches its maximum in April, and the number of days on which the maximum wind speed is over $10 \mathrm{~m} \mathrm{~s}^{-1}$ is also the highest in this month. The average wind velocity is $3.0-3.2 \mathrm{~m} \mathrm{~s}^{-1}$ in March-April, which are the most vulnerable to wind erosion. The main wind direction of winds above $5 \mathrm{~m} \mathrm{~s}^{-1}$ is northwestern (in the Transdanubian region) or north-eastern (on the Great Hungarian Plain). The regional distribution of wind velocity is very variable in Hungary: the strongest winds blow in the Transdanubian region. The number of windy days (when the wind velocity is above $10 \mathrm{~m} \mathrm{~s}^{-1}$ ) are about 122 per year, and the number of stormy days (when the wind velocity is above $15 \mathrm{~m} \mathrm{~s}^{-1}$ ) is about 32 days (MET, 2016).

\subsection{Wind tunnel measurement data}

The upper 0-20 $\mathrm{cm}$ ploughed layer was sampled at 215 sites from different parts of Hungary (Fig. 3a). Soil texture was the primary selection criterion for the assignment of sampling locations. Another important aspect was that each type should be represented by multiple samples; therefore, possible differences between samples belonging to the same texture class became comparable.

Wind tunnel measurements were carried out to determine the erodibility of Hungarian soils with different soil textures. The amount of the material transported by wind was calculated from the weight difference between the samples before and after the experiment. Weight loss was normalised to an erosion modulus $\left(\mathrm{th}^{1} \mathrm{~min}^{-1}\right)$ to quantify the wind erosion transport rate. Erosion modulus for velocity was calculated by dividing average accumulative soil loss by duration. The applied wind velocity was $16 \mathrm{~m} \mathrm{~s}^{-1}$ (which is the maximum wind velocity available in wind tunnel). According to the measured data we created three erodibility categories on the basis of the amount of transported material:

- strongly erodible: $1500-3200 \mathrm{~g} / 5 \mathrm{~min}$ $\left(64 \mathrm{tha}^{-1} \mathrm{~min}^{-1}\right)$,

- moderately erodible: $1000-1500 \mathrm{~g} / 5 \mathrm{~min}$ (30 tha $^{-1} \mathrm{~min}^{-1}$ ),

- slightly erodible: $0-1000 \mathrm{~g} / 5 \mathrm{~min}\left(20 \mathrm{tha}^{-1} \mathrm{~min}^{-1}\right)$.

Threshold wind velocity data were evaluated according to the texture classification of the samples (Table 1), whose result was applied in the parametrization of the countrywide soil texture map compiled for the uppermost $(0-5 \mathrm{~cm})$ soil layer.

\subsection{Spatial soil data}

Hungarian Soil Information and Monitoring System (SIMS, 1995) contains relevant particle size distribution data on more than 1200 locations (Fig. 3b). SIMS particle size distribution data were converted into clay, silt and sand particlesize fractions according to the USDA size groups of mineral particles (USDA, 1987; Table 2, Fig. 4). In SIMS the soillayer-related data refer to different depth intervals. For standardisation we transformed the soil texture fraction values of each soil profile into standard depth intervals $(0-5,5-15$, 15-30, 30-60, 60-100 and 100-200 cm; defined by GlobalSoilMap, Arrouays, 2014) by equal-area spline interpolation (Bishop et al., 1999; Malone et al., 2009). For the present purpose the deduced values for the topsoil layer $(0-5 \mathrm{~cm})$ were used in the subsequent mapping process.

Spatial inference of particle size data was carried out by regression-kriging (RK; Hengl et al., 2004, 2007), a spatial prediction technique that uses environmental correlation and geostatistical interpolation as complementary spatial inference methods. It combines the regression of the dependent variable on auxiliary variables with kriging of the regression residuals. RK involves spatially exhaustive, auxiliary information in the mapping process. In the present mapping we used the following environmental covariates.

Topography was taken into account based on the $25 \mathrm{~m} \mathrm{dig}$ ital elevation model (EU-DEM, 2015) and its morphometric derivatives: aspect, channel network base level, diurnal anisotropic heating, elevation, general curvature, LS factor, mass balance index, multi-resolution index of ridge top flatness (MRRTF), multi-resolution index of valley bottom flatness (MRVBF), SAGA wetness index, slope, stream power index, real surface area, topographic position index, topographic wetness index and vertical distance to channel network. The terrain features were calculated from the DEM within SAGA GIS (Bock et al., 2007).

Lithology was represented by the Geological Map of Hungary 1:100000 (Gyalog and Síkhegyi, 2005). In order to simplify the huge amount of lithology and facies categories, they were correlated with the nomenclature of parent material defined in the FAO Guidelines for soil description 
Table 1. Aggregated threshold wind velocity values by texture class.

\begin{tabular}{lrl}
\hline $\begin{array}{l}\text { Texture (number of soil } \\
\text { samples is in brackets) }\end{array}$ & $\begin{array}{r}\text { Threshold wind velocity (variability of } \\
\text { threshold wind velocity is in brackets) }\end{array}$ & $\begin{array}{l}\text { Empirical erodibility } \\
\text { classification }\end{array}$ \\
\hline Loam (15) & $9.7 \mathrm{~m} \mathrm{~s}^{-1}\left(9.5-9.8 \mathrm{~m} \mathrm{~s}^{-1}\right)$ & Moderately erodible \\
Silt loam (20) & $10.0 \mathrm{~m} \mathrm{~s}^{-1}\left(9.7-10.3 \mathrm{~m} \mathrm{~s}^{-1}\right)$ & Moderately erodible \\
Clay loam (7) & $11.0 \mathrm{~m} \mathrm{~s}^{-1}\left(10.8-11.3 \mathrm{~m} \mathrm{~s}^{-1}\right)$ & Slightly erodible \\
Silty clay loam (7) & $10.2 \mathrm{~m} \mathrm{~s}^{-1}\left(10.1-10.3 \mathrm{~m} \mathrm{~s}^{-1}\right)$ & Slightly erodible \\
Silty clay (5) & $11.5 \mathrm{~m} \mathrm{~s}^{-1}\left(11.2-11.7 \mathrm{~m} \mathrm{~s}^{-1}\right)$ & Slightly erodible \\
Clay (5) & $12.0 \mathrm{~m} \mathrm{~s}^{-1}\left(11.7-12.3 \mathrm{~m} \mathrm{~s}^{-1}\right)$ & Slightly erodible \\
Sandy clay loam (10) & $9.8 \mathrm{~m} \mathrm{~s}^{-1}\left(9.6-10.0 \mathrm{~m} \mathrm{~s}^{-1}\right)$ & Moderately erodible \\
Sandy loam (45) & $8.7 \mathrm{~m} \mathrm{~s}^{-1}\left(8.5-8.9 \mathrm{~m} \mathrm{~s}^{-1}\right)$ & Strongly erodible \\
Loamy sand (34) & $7.3 \mathrm{~m} \mathrm{~s}^{-1}\left(7.1-7.5 \mathrm{~m} \mathrm{~s}^{-1}\right)$ & Strongly erodible \\
Sand (35) & $6.5 \mathrm{~m} \mathrm{~s}^{-1}\left(6.2-6.8 \mathrm{~m} \mathrm{~s}^{-1}\right)$ & Strongly erodible \\
Sandy clay (11) & $10.0 \mathrm{~m} \mathrm{~s}^{-1}\left(9.8-10.2 \mathrm{~m} \mathrm{~s}^{-1}\right)$ & Moderately erodible \\
Silt (11) & $10.5 \mathrm{~m} \mathrm{~s}^{-1}\left(10.3-10.8 \mathrm{~m} \mathrm{~s}^{-1}\right)$ & Slightly erodible \\
Organic material & n.a. & Non-erodible \\
Water & n.a. & Non-erodible \\
Bedrock & n.a. & Non-erodible \\
Sealed soil & n.a. & Non-erodible \\
\hline
\end{tabular}

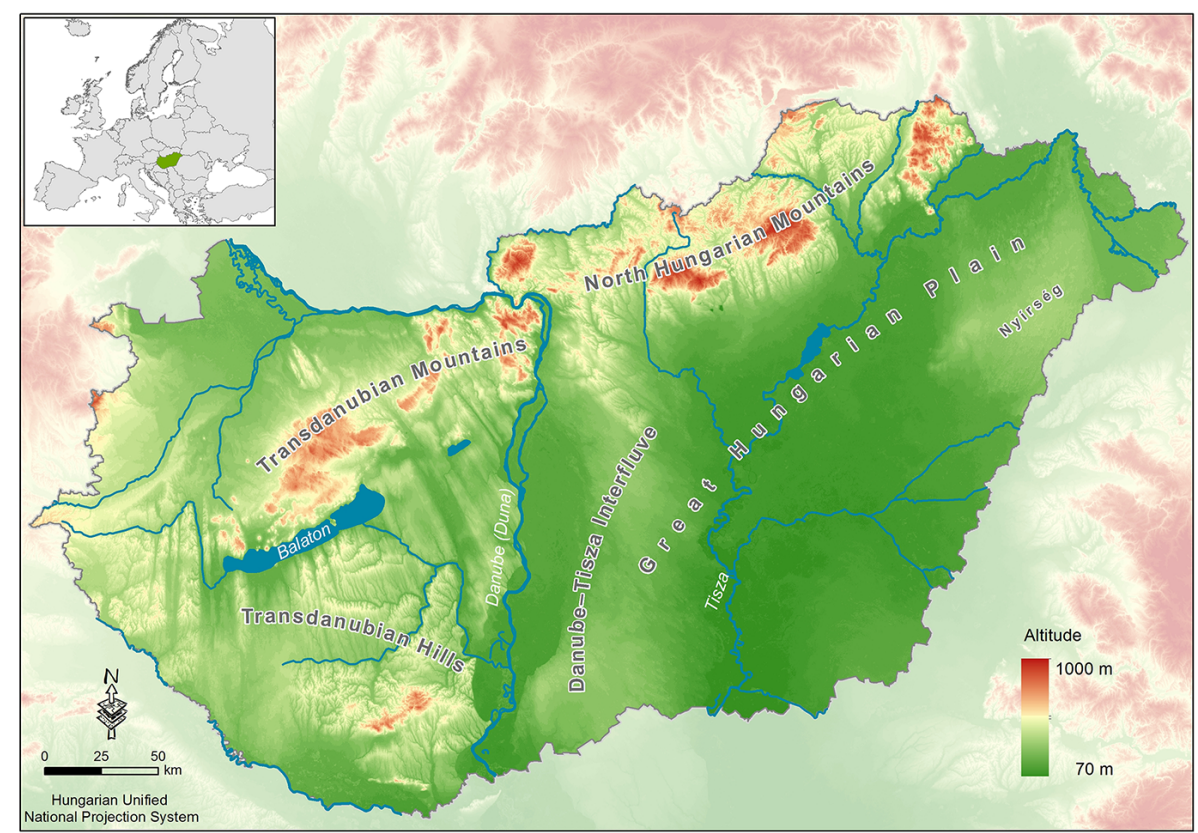

Figure 2. Hungary's general geographical conditions.

(FAO, 2006; Bakacsi et al., 2014). Some FAO categories were merged in order to increase the correlation with soil particle size distribution.

Climate was represented by four relevant layers: average annual precipitation, average annual temperature, average annual evaporation and evapotranspiration. The spatial layers were compiled using the MISH method elaborated for the spatial interpolation of surface meteorological elements based on 30-year observation of the Hungarian Meteoro- logical Service with $0.5^{\prime}$ resolution (Szentimrey and Bihari, 2007).

Physical soil property map contained by the Digital Kreybig Soil Information System (DKSIS, Pásztor et al., 2012) provided further spatial ancillary information (Pásztor et al., 2016). The categories used in legacy maps are defined according to water retention capability, permeability and infiltration rate of soils and they are closely related to the texture classes; however, they cannot be considered identical. 
(a)

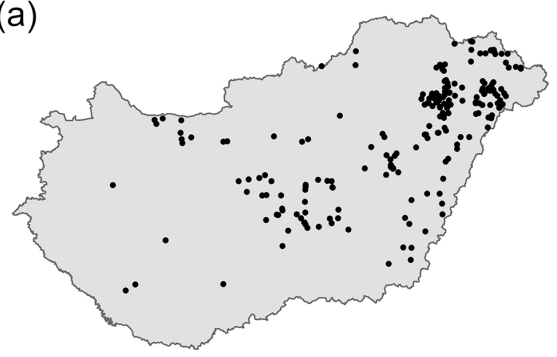

(c)

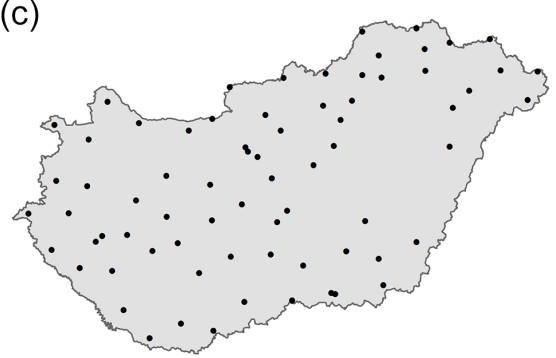

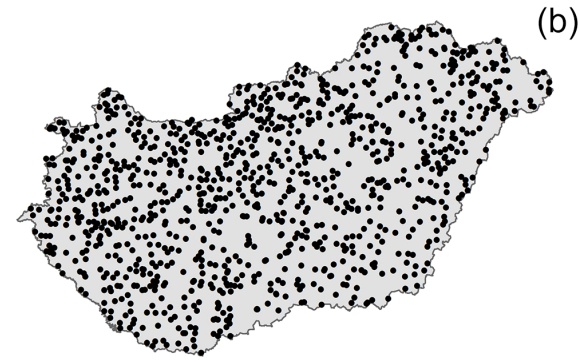

(b)

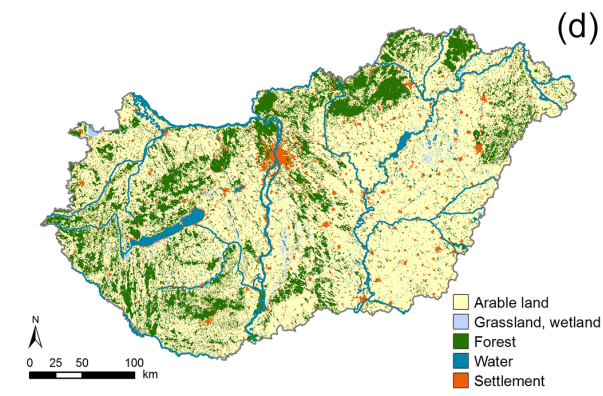

Figure 3. The spatial distribution of sampling points used in the present study: soil sample locations used in wind tunnel measurements (a), SIMS location used in the compilation of soil fractions and texture maps (b), meteorological stations used in long-term wind speed calculations (c), and Hungary's general land cover conditions (d).

Table 2. Conversion of SIMS particle size distribution data into clay, silt and sand particle-size fractions according to the USDA size groups of mineral particles.

\begin{tabular}{ll}
\hline $\begin{array}{l}\text { SIMS particle } \\
\text { size }(\mathrm{mm})\end{array}$ & $\begin{array}{l}\text { Particle-size } \\
\text { fraction }\end{array}$ \\
\hline$<0.002$ & CLAY \\
$0.002-0.005$ & SILT \\
$0.005-0.01$ & \\
$0.01-0.02$ & \\
$0.02-0.05$ & \\
$0.05-0.2$ & SAND \\
$0.2-2$ & \\
\hline
\end{tabular}

In order to harmonise the different spatial resolutions of the predictor variables, we resampled them into a common $100 \mathrm{~m}$ grid system (SAGA GIS; Bock et al., 2007), which also defines the spatial resolution of the result map. All of the auxiliary variables were normalised to a $0-255$ value scale, and resampled into a common grid system. Categorical variables were considered as indicator variables. Every category got a new layer: in case of occurrence, the grid value was set to 255 , while out-of-category areas were coded with 0 . Principal component analysis (PCA) was performed on the continuous environmental auxiliary variables and the resulted principal components (PCs) were used in further procedures. Since PCs are orthogonal and independent, they satisfy the requirements of multiple linear regression analysis (MLRA) and also decrease multicollinearity.

\section{Soil textural triangle}

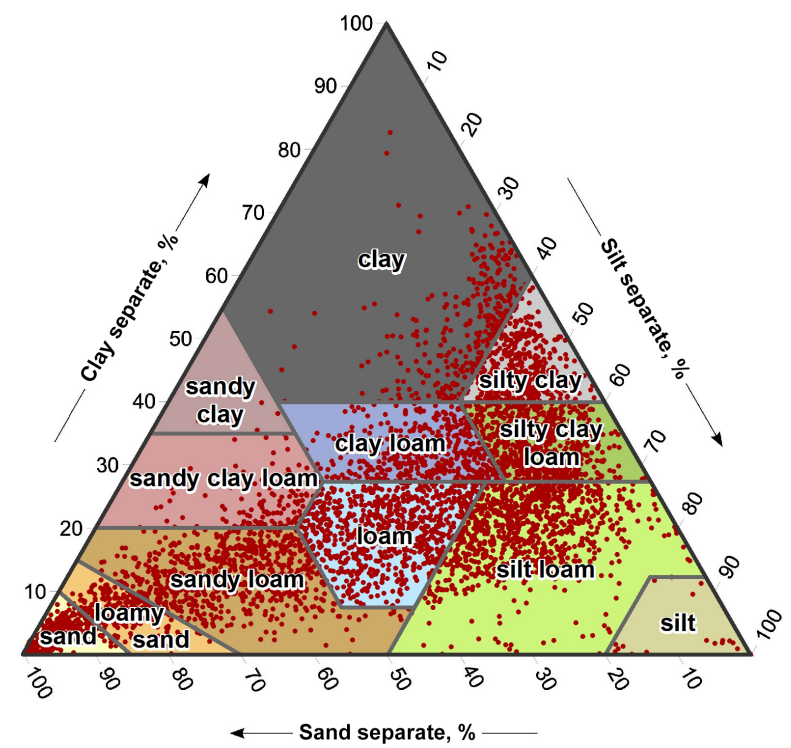

Figure 4. The texture triangle with USDA classification and the distribution of SIMS points.

Since clay, silt and sand contents are compositional variables (their sum must be $100 \%$ ), instead of inferring the maps independently composite kriging was applied based on additive log-ratio (alr) transformation (Aitchison, 1986; Lark and Bishop, 2007; Ballabio et al., 2016) of the original three variables. The texture class map itself was compiled accord- 
ing to the USDA categories based on the proper pixel-bypixel combination of the three particle size distribution maps. Certain areas (like organic or sealed soil, outcrops and water) cannot be featured by soil texture, so the map treats them independently without providing spatial prediction for them. The compiled map is displayed in Fig. 5.

\subsection{Wind speed data and their spatial inference}

Wind speed data were provided and processed by the Hungarian Meteorological Service. The aim was to determine how frequently wind speed exceeds a certain critical speed value in each grid point of a dense $0.5^{\prime}$ spatial resolution grid. In order to ensure highest quality of background data several regards were taken into consideration. Before the 1990s the Hungarian Meteorological Service operated manned synoptic stations that measured wind speed in a different manner than in recent years. At most stations wind speed was observed only every 3 or $6 \mathrm{~h}$, and only a limited number of stations were equipped with anemographs. By the year 2000 almost all stations had received new automatic instruments capable of continuous measurements; therefore, the decision was to use hourly average wind speed data starting from 2000 through 2013. Selection criteria for stations were that the number of missing data should not exceed $10 \%$ (out of thirteen years' 113952 entries of hourly data) in the station's dataset. Altogether 72 stations (Fig. 3c) met these requirements.

The next step was to produce values on a dense grid covering the area of Hungary. This was carried out by applying the MISH (Meteorological Interpolation based on Surface Homogenised Data Basis; Szentimrey and Bihari, 2007) method for gridding of hourly station data. It was developed at the Hungarian Meteorological Service specifically for the interpolation of meteorological data, and it is based on the idea that the highest quality interpolation formula can be obtained when certain statistical parameters are known. These parameters are derived by modelling, using long term homogenised data of neighbouring stations. The MISHv1.03 software first carries out the modelling of statistical parameters, using additional variables such as topography, height of measurement or roughness length. The interpolation itself is achieved in the second step, using an interpolation formula that depends on the output of the modelling system. Therefore the obtained value of a grid point is determined not only by the values of the actual time step, but the long term climatic data of the neighbouring stations as well.

Due to the immense computation demand of gridding, the MISH method limits the number of predictor series to 2000, the length of the series to 4000 and the predictand locations to 10000 . The predictor series were the 72 station series, but - taking into consideration the hourly measured data - they had much more than 4000 values each and the predictands of a $0.5^{\prime}$ grid were much more than the limit as well. The problem of the length of series was overcome by splitting the series into fragments, and gridding of hourly data was done separately for each month. Moreover, each month's data were split into three parts to fit the 4000 limit of length. In order to meet the limit of prediction locations the grid had to be truncated. Considering that the spatial variance of wind speed is much less above flat terrain, an iteration formula was developed to determine the best grid network that has at most 10000 grid points but is preferably denser around mountainous regions. The fragments were all gridded onto this somewhat irregular grid of 9984 predictand points and then finally merged together into one file. The dense $0.5^{\prime}$ resolution grid was then matched with the 9984 predictand values in the manner of finding the closest predictand point to each point of the dense grid; thus, values of each point were ultimately acquired.

\subsection{Land cover}

CORINE Land Cover 1:50000 (CLC50; Büttner et al., 2004) was used for representing the role of land use and land cover in modelling the exposure of land to wind erosion. CLC50 is a national land cover database (Fig. 3d) elaborated on the basis of the CORINE nomenclature of the European Environment Agency (EEA) and adapted to fit the characteristics of Hungary. However, CLC50 is not the most recent version of CORINE databases (it was prepared in 2000), but its spatial resolution is significantly finer since the smallest delineated unit is 4 and 1 ha in the case of water bodies.

According to CLC50, about $56 \%$ of Hungary is under agricultural cultivation while about $44 \%$ of the country's area features land characteristics, which are more resistant to wind erosion. Since wind erosion does not typically occur in artificial surfaces (1), forests and semi-natural areas (3), some agricultural areas $(212,213,221,222,231,242,243)$ and over water bodies (5), these areas were consequently masked out (the numbers in brackets are according to the CLC50 nomenclature).

\section{Results and discussion}

\subsection{Critical wind speed exceedance map}

The outcome of wind speed exceedance calculations was the probability value of wind velocity exceeding critical values on an hourly level during the observed 13 years in each point of the grid network (Fig. 6). According to the map, spatial variability is relatively high throughout the country. Values in general range from 0 to above $2.5 \%$ in relation to wind climatology, landscape, soil properties and land cover.

Most of Hungary has values smaller than $0.5 \%$; moreover, a significant portion of the country presents probability values that do not exceed $0.01 \%$. These regions, in particular the western borderline, most of the North Hungarian Mountains (the subsequently mentioned geographical names are displayed in Fig. 2), southern Transdanubia and several 


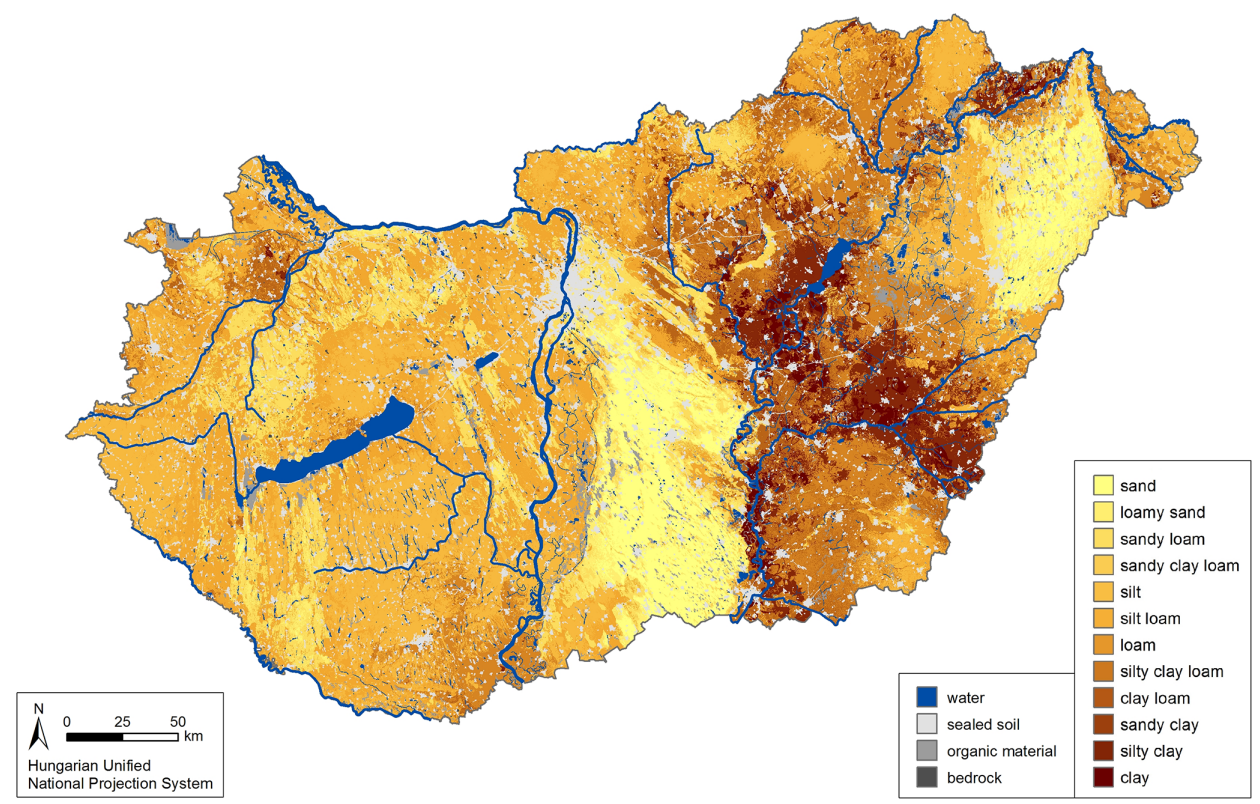

Figure 5. Hungary's soil texture map of the uppermost layer $(0-5 \mathrm{~cm})$ according to USDA categorisation.

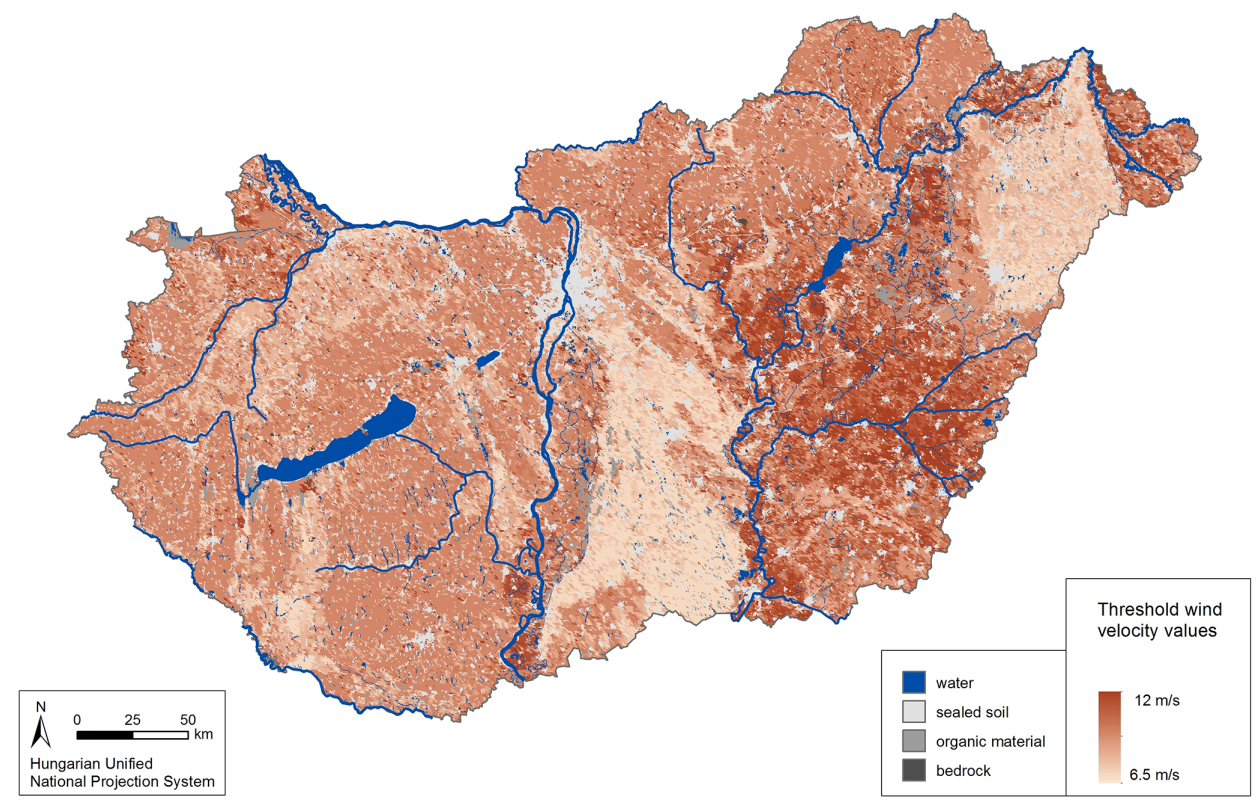

Figure 6. Threshold wind velocity values linked to the centres of the $0.5^{\prime}$ resolution grid based on the soil texture map.

patches scattered across the Great Plain are characterized by wind speeds that virtually never reach critical values. Probabilities up to $0.5 \%$ appear to be predominant in areas east of the Danube excluding two major territories: most of the plain between the Danube and Tisza rivers, and the Nyírség in the Northern Great Plain, close to the north-eastern corner of the country. Wind speeds exceeding critical values are somewhat more prevalent in these regions, but probability values higher than $2 \%$ are still exceptionally rare. In the western half of Hungary, however, we can find more outstanding values. Around Lake Balaton, especially in the Transdanubian Mountains values higher than $1 \%$ are relatively common, and several smaller areas present probability values higher than $2.5 \%$, indicating a significantly higher probability of critical wind stress. 


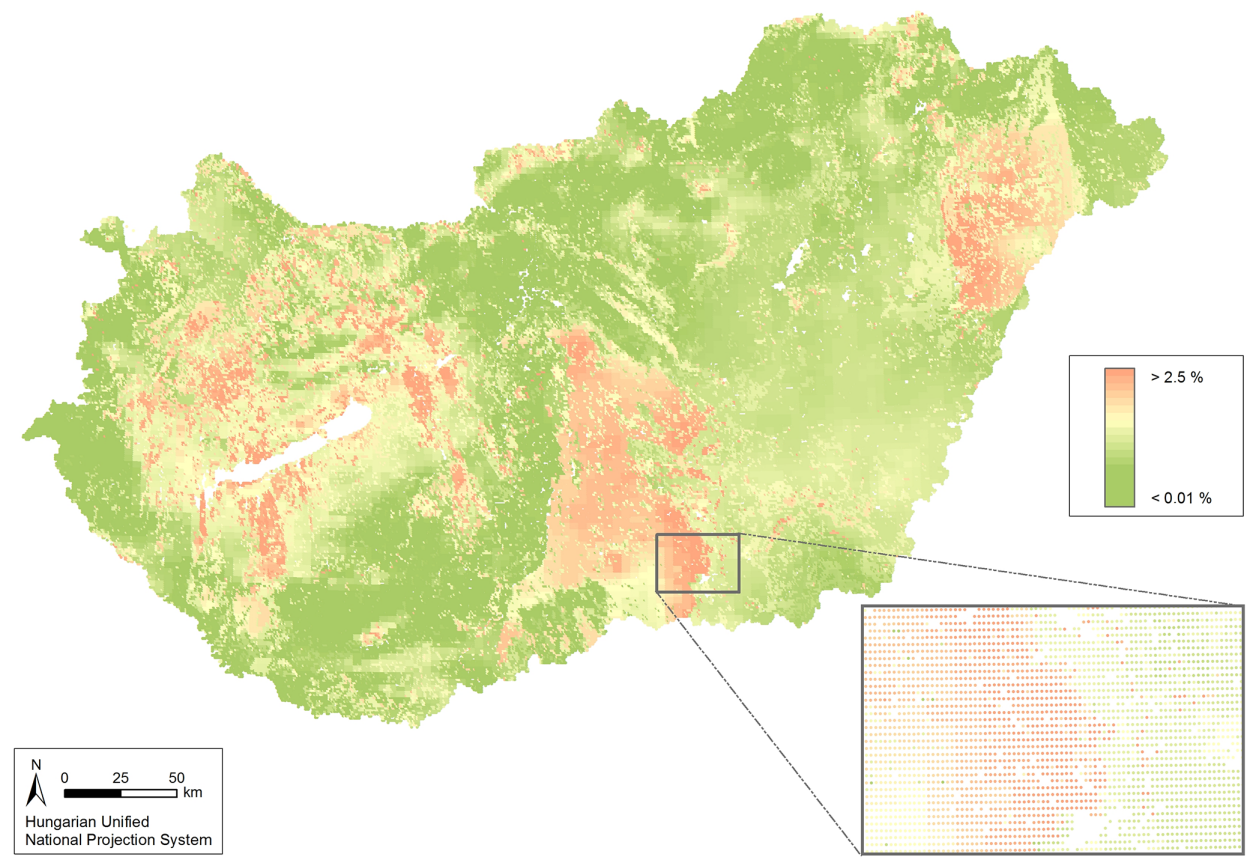

Figure 7. Probability values of hourly wind speed exceeding critical values (2000-2013) calculated for the $0.5^{\prime}$ resolution grid points.

Table 3. The extent of wind-susceptible areas in Hungary.

\begin{tabular}{lrr|rr}
\hline & \multicolumn{2}{c|}{$\begin{array}{c}\text { Spatial distribution based on } \\
\text { our combined modelling }\end{array}$} & \multicolumn{2}{c}{$\begin{array}{c}\text { Spatial distribution based } \\
\text { on Borrelli's data }\end{array}$} \\
\cline { 2 - 5 } Erodibility categories & Area $\left(\mathrm{km}^{2}\right)$ & Percentage $(\%)$ & Area $\left(\mathrm{km}^{2}\right)$ & Percentage (\%) \\
\hline Non-erodible & 29052.0 & 31.2 & 41707.5 & 44.8 \\
Slight erodibility & 54436.0 & 58.5 & 46375.0 & 49.8 \\
Moderate erodibility & 5208.0 & 5.6 & 4384.6 & 4.7 \\
High erodibility & 4333.0 & 4.7 & 562.9 & 0.6 \\
\hline Total & 93030.0 & 100.0 & 93030.0 & 100.0 \\
\hline
\end{tabular}

\subsection{Wind erosion susceptibility map}

The probability values of hourly wind speed exceeding critical value can already be considered as a proper indicator of wind erosion susceptibility. However, these values were inferred for the applied $0.5^{\prime}$ spatial resolution grid, which cannot be actually considered as a real map (Fig. 7). To create a spatially exhaustive map, the calculated values were further interpolated using co-kriging to a 1 ha spatial resolution grid. Sand and silt content of the uppermost $(0-5 \mathrm{~cm})$ soil layer, formerly used for the compilation of the reference soil texture map, were used as appropriate numerical co-variables. The final map (Fig. 8) was produced by masking out areas, which cannot be exposed to wind erosion due to their land use and/or land cover characteristics.

According to the compiled maps, roughly $10 \%$ of the country is affected by high risk of wind erosion. This is mainly a consequence of the vegetation cover and only sec- ondly the occurrence of erosive winds, that is wind with velocity exceeding the local critical threshold value. In the majority of the country the winds do not exceed critical velocity during the year, so despite the fact that the soil, land use and land cover conditions would make it possible, wind erosion harm occurs very rarely. Therefore, it can be expected merely in the case of strong cold fronts. In generally arable lands situated in lowlands and covered by sandy soils are the most endangered by wind erosion because they feature relatively small critical threshold velocity $\left(6-7 \mathrm{~m} \mathrm{~s}^{-1}\right)$, and consequently even winds with gentle energy are capable of transporting the upper soil layer.

The fine continuous scale of the wind erosion susceptibility map together with its high spatial resolution is not necessarily applicable for decision making in land management and spatial planning. Consequently, we created a simplified version of the map (Fig. 9). We classified the probability values of hourly wind speed exceeding critical value into 


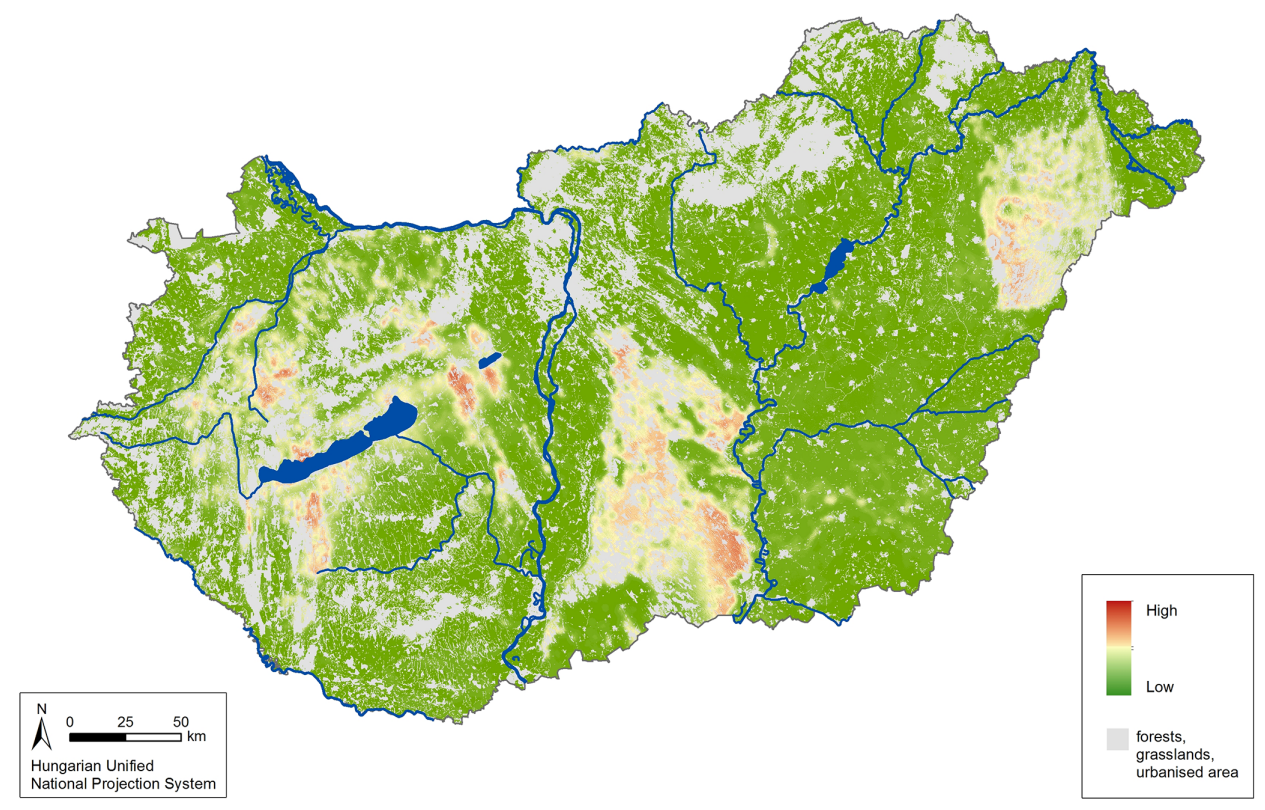

Figure 8. Wind erosion susceptibility map of the Hungarian soils.

three categories based on statistical properties of its distribution, which was supplemented with a fourth category of non-erodible areas according to CLC50.

According to the categorised map five distinct territories can be identified in the areas with typically higher wind erosion risk:

1. The Nyírség is an ancient alluvial fan. Its area is about $5100 \mathrm{~km}^{2}$ and consists of mainly sandy soils and their variants. About one third of the area is covered by forests (mainly the aeolian form), but there is a difference in this regard in regional distribution because territories covered by sandy loam, loam and silty loam are under agricultural cultivation and are more endangered by wind erosion.

2. The Danube-Tisza Interfluve is about $10000 \mathrm{~km}^{2}$ and also consists of sandy soils and their variants. A significant discrepancy between this region and the Nyírség is that this area is poorer in precipitation $(500-550 \mathrm{~mm})$ and there are drought periods in many years. As a consequence of its drier climate, its forest cover is sparser than in the Nyírség.

3. The glacis in the foreground of the Transdanubian Mountains are affected by wind erosion for mainly two reasons. On the one hand, they are covered by sandy soils, and on the other hand, the wind velocity here is the highest in Hungary because this region is exposed perpendicularly to the dominant winds blowing from the north-west.

4. The Inner Somogy is about $3000 \mathrm{~km}^{2}$. However, it has more precipitation than the Nyírség and the Danube-
Tisza Interfluve. According to the alluvial fan origin of the area, it is also covered by sandy soils, which make it more endangered by wind erosion.

The productivity of the soils formed in the Transdanubian loess region is outstanding, making the land dominantly arable. This territory is also exposed perpendicularly to the winds blowing from the north-west, which, together with the seasonally uncovered and extended agricultural areas, make it more susceptible to wind erosion.

\section{Conclusions}

Comparing our results to those of others (Borreli at al., 2014; Funk and Reuter, 2006), we can conclude that the regional distribution of areas that feature a higher risk of wind erosion is in good agreement with our results. Table 4 compares the extent of wind-susceptible areas in Hungary according to our categorisation with that inferred by Borrelli et al. (2014). In spite of the generic methodological differences, the figures are quite similar. Stefanovits and Várallyay (1992) evaluated the extent of wind erosion based on the costs payed out by insurance companies for wind erosion harms and their results coincide very well with our findings. Mezősi et al. (2015), also got similar results based on less detailed input data. Albeit the main pattern of previous approaches is reflected with reliable accuracy, the recent map can be considered as a specific zooming in on the spatial behaviour of wind erosion due to the application of significantly more detailed input data.

The applied climatic parameter, namely ratio of hourly wind speed exceeding critical values, proved to be a fairly applicable indicator for the characterisation and mapping of 


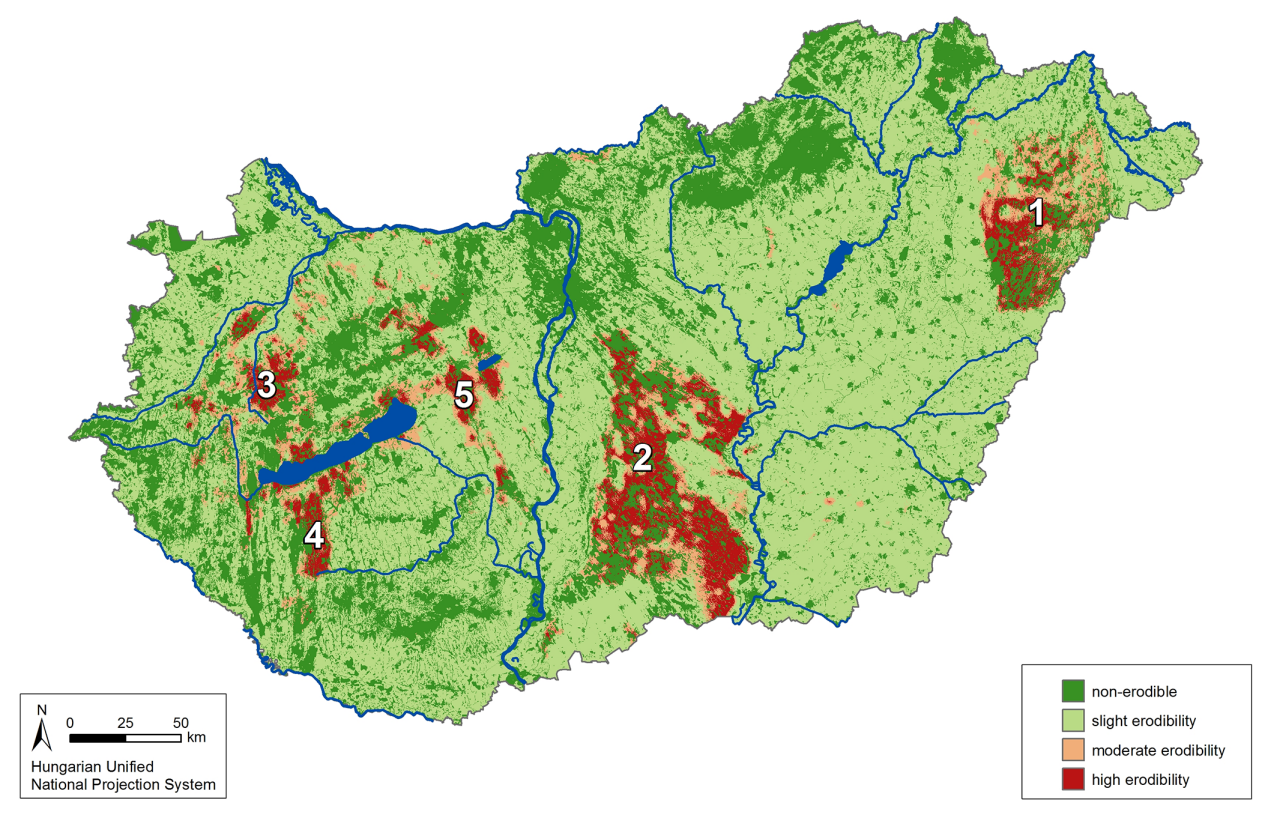

Figure 9. Categorised wind erosion susceptibility map of the Hungarian soils. The five distinct areas with typically higher wind erosion risk are numbered: Nyírség (1), Danube-Tisza Interfluve (2), glacis in the foreground of the Transdanubian Mountains (3), Inner Somogy (4), Transdanubian loess region (5).

wind erosion risk. We consider the present parameter fully informative since it also takes into consideration the duration of the winds exceeding the critical threshold values. The comparison of this parameter with other ones, which are used for the description of wind features (number of stormy days, number of days with winds over a critical threshold, etc.) could be a potential further step.

We would like to emphasise that the derived wind erosion map displays the current actual static state. The wind erosion cause and affect factors (land cover and/or land use, soil moisture content, management technology) vary both spatially and temporally. Aside from soil moisture content, the applied management technology plays an important role since the structure of soils even with identical texture category may be differently damaged due to improper management techniques. Information on this factor could be collected by field observations and/or large scale mapping. However, detailed and timely data, which could be used for nationwide mapping, are not currently available and cannot even be expected in the near future. A suitable solution could be the proper implication of these factors into process models and scenario-based runs of the developed models.

We see some further possibilities for the improvement of the presented approach. It would be a major step forward to functionally relate the resistance of soils to wind erosion with their erodibility factor (EF), which can be calculated from basic soil properties (sand, silt, clay, organic matter and carbonate content), instead of leaning on texture classes. In this case critical threshold values could be estimated directly by $\mathrm{EF}$ and also indirectly by widely used soil data. Since nation- wide soil property maps of these parameters have been very recently compiled, they could support a new approximation for mapping wind erosion susceptibility on a national level. Eliminating the application of class averages, the expected accuracy of both thematic and spatial prediction is suggested to be improved.

The compiled map in its present form provides a solid basis for the regional characterisation of wind erosion risk. It can be used for rational planning of protection concerning both soil conservation and environmental risk management.

\section{Data availability}

Acknowledgements. This research was supported by the Hungarian Research Scientific Fund (OTKA) PD115803 and K105167.

Edited by: P. Bartelt

Reviewed by: two anonymous referees

\section{References}

Aitchison, J.: The statistical analysis of compositional data, Chapman \& Hall, London, p. 416, 1986.

Armbrust, D. V. and Bilbro, J. D.: Relating plant canopy characteristics to soil transport capacity by wind, Agron. J., 89, 157-162, 1997.

Arrouays, D., McKenzie, N., Hempel, J., De Forges, A. R., and McBratney, A. B. (Eds.): GlobalSoilMap, Taylor \& Francis Group, London, p. 494, 2014. 
Bakacsi, Z., Laborczi, A., Szabó, J., Takács, K., and Pásztor, L.: Proposed correlation between the legend of the 1:100.000 scale geological map and the FAO code system for soil parent material, Agrokem, Talajtan, 63, 189-202, 2014.

Ballabio, C., Panagos, P., and Monatanarella, L.: Mapping topsoil physical properties at European scale using the LUCAS database, Geoderma, 261, 110-123, 2016.

Bärring, L., Jönsson, P., Mattsson, J. O., and Åhman, R.: Wind erosion on arable land in Scania, Sweden and the relation to the wind climate - a review, Catena, 52, 173-190, 2003.

Bishop, T. F. A., McBratney, A. B., and Laslett, G. M.: Modelling soil attribute depth functions with equal-area quadratic smoothing splines, Geoderma, 91, 27-45, 1999.

Bock, M., Böhner, J., Conrad, O., Köthe, R., and Ringeler, A.: Methods for creating Functional Soil Databases and applying Digital Soil Mapping with SAGA GIS, in: Status and prospect of soil information in south-eastern Europe: soil databases, projects and applications, edited by: Hengl, T., Panagos, P., Jones, A., and Toth, G., Office for Official Publications of the European Communities, Luxemburg, 149-162, 2007.

Böhner, J., Schäfer, W., Conrad, O., Gross, J., and Ringeler, A.: The WEELS model: methods, results and limitations, Catena, 52, 289-308, 2003.

Borrelli, P., Ballabio, C., Panagos, P., and Montanarella, L.: Wind Erosion Susceptibility of European Soils, Geoderma, 232, 471478, 2014a.

Borrelli, P., Panagos, P., Ballabio, C., Lugato, E., Weynants, M., and Montanarella, L.: Towards a Pan-European assessment of land susceptibility to wind erosion, Land Degrad. Dev., 27, 10931105, doi:10.1002/ldr.2318, 2014b.

Borrelli, P., Panagos, P., and Montanarella, L.: New Insights into the Geography and Modelling of Wind Erosion in the European Agricultural Land. Application of a Spatially Explicit Indicator of Land Susceptibility to Wind Erosion, Sustainability, 7, 88238836, 2015.

Büttner, G., Maucha, G., Bíró, M., Kosztra, B., Pataki, R., and Petrik, O.: National land cover database at scale 1:50000 in Hungary, EARSeL eProceedings, 3, p. 8, 2004.

Eppink, L. A. A. J. and Spaan, W. P.. Agricultural wind erosion control measures in the Netherlands, Soil Technol., 1, 1-13, 1989.

EU-DEM: Digital Elevation Model over Europe, European Environment Agency, available at: http://www.eea.europa.eu/ data-and-maps/data/eu-dem (last access: 12 January 2016), 2015.

European Environment Agency (EEA): Europe's Environment: The Second Assessment, EEA, Copenhagen, p. 293, 1998.

FAO: Guidelines for soil description, 4th edition, Rome, FAO, p. 97 , 2006.

Fryrear, D. W., Bilbro, J. D., Saleh, A., Schomberg, H., Stout, J. E., and Zobeck, T. M.: RWEQ: Improved wind erosion technology, J. Soil Water Conserv., 55, 183-189, 2000.

Funk, R. and Reuter, H. I.: Wind erosion, in: Soil erosion in Europe, edited by: Poesen, J., Wiley, Chichester, 563-582, 2006.

Funk, R., Deumlich, D., Voelker, L., and Steidl, J.: GIS application to estimate the wind erosion risk in the Federal State of Brandenburg, in: Wind Erosion and Dust Dynamics, edited by: Goossens, D. and Riksen, M., ESW Publications, Wageningen, 139-150, 2004.
Gomes, L., Arrue, J. L., López, M. V., Sterk, G., Richard, D., Gracia, R., and Frangi, J. P.: Wind erosion in a semiarid agricultural area of Spain: the WELSONS project, Catena, 52, 235-256, 2003.

Goossens, D.: The on-site and off-site effects of wind erosion, in: Wind Erosion on Agricultural Land in Europe, edited by: Warren, A., Office for Official Publications of the European Communities, Luxembourg, 29-38, 2001.

Gyalog, L. and Síkhegyi, F.: Geological Map of Hungary, $1: 100$ 000, Geological Institute of Hungary, Budapest, available at: http://loczy.mfgi.hu/fdt100/ (last access: 15 December 2015) 2005.

Hartemink, A. E., Mcbratney, A. B., and De Mendonça-Santos, L. (Eds.): Digital Soil Mapping with Limited Data, Springer, the Netherlands, 445 pp., 2008.

Hengl, T. Heuvelink, G. B. M., and Stein, A.: A generic framework for spatial prediction of soil variables based on regressionkriging, Geoderma, 120, 75-93, 2004.

Hengl, T., Heuvelink, G. B. M., and Rossiter, D. G.: About regression-kriging: From equations to case studies, Comp. Geosci., 33, 1301-1315, 2007.

Lagacherie, P., Mcbratney, A. B., and Voltz, M. (Eds.): Digital soil mapping: an introductory perspective, Amsterdam, Elsevier, 658 pp., 2007.

Lal, R.: Methods and guidelines for assessing sustainable use of soil and water resources in the tropics, prepared for Soil Management Support Services, US Department of Agriculture Soil Conservation Service, and US Agency for International Development, SMSS Technical Monograph 21, Ohio State University, Department of Agronomy, p. 88, 1994.

Lancaster, N.: Geomorphology of desert dunes. Routledge, p. 290, 1995.

Lark, R. M. and Bishop, T. F. A.: Cokriging particle size fractions of the soil, Eur. J. Soil Sci., 58, 763-774, 2007.

Lóki, J.: Aeolian processes, in: Recent landform Evolution: The Carpatho-Balkan-Dinaric Region, edited by: Lóczy, D., Stankoviansky, M., and Kotarba, A., Springer, 205-247, 2012.

López, M. V., Sabre, M., Gracia, R., Arrue, J. L., and Gomes, L.: Tillage effects on soil surface conditions and dust emission by wind erosion in semiarid Aragon (NE Spain), Soil Tillage Res., 45, 91-105, 1998.

Malone, B. P., McBratney, A. B., Minasny, B., and Laslett, G. M.: Mapping continuous depth functions of soil carbon storage and available water capacity, Geoderma, 154, 138-152, 2009.

Martinez-Grana, A. M., Goy, J. L., and Zazo, C.: Cartographic prodecure for the analysis of aeolian erosion hazard in natural parks (Central System, Spain), Land Degrad. Dev., 26, 110-117, 2015.

McBratney, A. B., Mendonça-Santos, M. L., and Minasny, B.: On digital soil mapping, Geoderma, 117, 3-52, 2003.

MET 2016: available at: http://www.met.hu/eghajlat/ magyarorszag_eghajlata/altalanos_eghajlati_jellemzes/szel/ last access: 2 April 2016.

Mezősi, G., Blanka, V., Bata, T., Kovács, F., and Meyer, B.: Estimation of regional differences in wind erosion sensitivity in Hungary, Nat. Hazards Earth Syst. Sci., 15, 97-107, doi:10.5194/nhess-15-97-2015, 2015. 
Minasny, B., Malone, B. P., and Mcbratney, A. B. (Eds.): Digital Soil Assessments and Beyond, Taylor \& Francis Group, London, p. 466, 2012.

Oldeman, L. R., Hakkeling, R. T. A., and Sombroek, W. G.: World map of the status of human-induced soil degradation: An explanatory note, Wageningen, the Netherlands and Nairobi, Kenya, International Centre and United Nations Environment Programme, 1991.

Pásztor, L., Szabó, J., Bakacsi, Z., Matus, J., and Laborczi, A.: Compilation of 1:50000 scale digital soil maps for Hungary based on the Digital Kreybig Soil Information System, J. Maps, 8, 215-219, 2012.

Pásztor, L., Laborczi, A., Takács, K., Szatmári, G., Dobos, E., Bakacsi, Z., and Szabó, J.: Compilation of novel and renewed, goal oriented digital soil maps using geostatistical and data mining tools, Hung. Geogr. Bull., 64, 49-64, 2015.

Pásztor, L., Laborczi, A., Takács, K., Bakacsi, Z., and Szabó, J.: Variations for the implementation of SCORPAN's "S", in: Digital Soil Mapping Across Paradigms - Scales and Boundaries, edited by: Zhang, G. L., Brus, D. J., Liu, F., Songm X. D., and Lagacherie, P., Springer, 331-342, 2016.

Péczely, G.: Éghajlattan, Nemzeti Tankönykiadó, 258-285, 1998.

Shao, Y.: Physics and modelling of wind erosion, 2nd ed. SpringerVerlag, 393 pp., 2008.
SIMS (Hungarian Soil Information and Monitoring System): Methodology, Ministry of Agriculture, Plant Protecting and Agro-ecological Department, p. 92, 1995.

Stefanovits, P. and Várallyay, G.: State and management of soil erosion in Hungary, Proceedings of the Soil Erosion and Remediation Workshop, US - Central and Eastern European AgroEnvironmental Program, Budapest, vol. I, 79-95, 1992.

Szentimrey, T. and Bihari, Z.: Mathematical background of the spatial interpolation methods and the software MISH (Meteorological Interpolation based on Surface Homogenized Data Basis), in: Proceedings from the Conference on Spatial Interpolation in Climatology and Meteorology, Budapest, Hungary, 2004, COST719 Meeting, 17-27, 2007.

USDA: Soil Mechanics Level I. Module 3 - USDA Textural Soil Classification Study Guide. National Employee Development Staff, Soil Conservation Service, United States Department of Agriculture, p. 48, 1987.

Warren, A.: Wind erosion on agricultural land in Europe: research results for land managers, Office for Official Publications of the European Communities, Luxembourg, p. 78, 2003.

Zheng, X.: Mechanics of wind-blown sand movements, SpringerVerlag Berlin Heidelberg, p. 309, 2009. 